\title{
Penerapan Pembelajaran Metode Kerja Kelompok Untuk Meningkatkan Hasil Belajar Pkn Siswa Kelas V Semester Ganjil SDN 2 Ngali Tahun Pelajaran 2016/2017
}

\author{
Iswan \\ SDN 2 Ngali \\ Email: iswan_sdn2ngali67@gmail.com
}

\begin{abstract}
Abstrak. Untuk membentuk anak menjadi demokratis kita harus menekankan pelaksanaan prinsip kerjasama lebih besar faedahnya dan pada sistem persaingan. Kerja kelompok mempertinggi hasil belajar baik secara kualitatif maupun kuantitatif. Penelitian ini bertujuan untuk mengetahui Penerapan Pembelajaran Metode Kerja Kelompok dalam Meningkatkan Hasil Belajar Pkn Siswa Kelas V Semester Ganjil SDN 2 Ngali Tahun Pelajaran 2016/2017. Jenis ini adalah Penelitian Tindakan Kelas (PTK), Desain Penelitian Tindakan Kelas yang digunakan sesuai dengan model PTK Kemmis dan McTaggart. Setiap siklus meliputi perencanaan (plan), tindakan (action), pengamatan (observation), evaluasi (evaluation) serta refleksi (reflection). Subyek dalam penelitian ini adalah siswa Kelas V SDN 2 Ngali Semester I sebanyak 27 orang. Instrumen yang digunakan dalam penelitian ini adalah soal tes dan lembar observasi. Berdasarkan analisis data yang telah dilakukan maka disimpulkan bahwa: (1) Rata-rata hasil belajar PKn siswa sebelum penelitian tindakan kelas adalah 16,244 dan skor ideal yang mingkin dicapai yaitu 25, sedangkan rata-rata hasil belajar PKn siswa setelah diadakan tindakan kelas melalui metode kerja kelompok dengan bantuan tutor sebaya dan dua siklus yaitu Siklus I adalah 27,089 dan siklus II adalah 30,60, dan skor ideal yang dicapai yaitu 40. Dari hasil tersebut diperoleh keterangan bahwa hasil belajar PKn dalam hal ini kemampuan menyelesaikan soal-soal siswa kelas V SDN 2 Ngali mengalami peningkatan. (2)Adanya peningkatan ketuntasan hasil belajar yakni sebelum diadakan tindakan tes awal 35,56\%) yang tuntas, setelah diadakan tindakan siklus I 72,50\% yang tuntas, dan Siklus II 97,50\% yang tuntas. DARI Hasil ini diperoleh keterangan bahwa siklus II ini telah mencapai ketuntasan belajar secara klasikal sebagaimana yang telah ditetapkan oleh Depdiknas bahwa tuntas belajar secara klasikal jika telah mencapai $85 \%$ dari jumlah siswa yang telah memperoleh skor minimal $65 \%$ dan skor ideal.
\end{abstract}

Keywords: Kerja kelompok, Hasil belajar

\section{PENDAHULUAN}

Hasil belajar pendidikan Kewarganegaraan yang belum maksimal merupakan salah satu masalah bagi mutu pendidikan.hal ini dapat dilihat dari rendahnya daya serap pada setiap semester yang di peroleh siswa pada tahun pelajaran 2016/2017 rata-ratanya hanya 62,15 ini tergolong kategori sedang bila dibandingkan dengan mata pelajaran lain. Demikian pula pada sdn 2 ngali hasil belajar pkn sampai saat ini belum optimal.hal ini disebabkan oleh beberapa faktor, baik yang berasal dari dalam siswa itu sendiri maupun dan luar siswa.

Banyak siswa yang tidak hanya kurang mampu memahami konsep konsep dan pehamaman yang dianjarkan oleh guru. Ini disebabkan kebanyakan siswa menganggap bahwa pelajaran PKN merupakan pelajaran hafalan saja. Di dalam duia pendidikan, diperlukan suatu usaha dalam percampaian tujuan pengajaran melalui proses belajar mengajar yang efektif dan efisien, hal ini sejalan dengan yang diungkapkan oleh winarno surakhmad (1994:14) bahwa: pendidikan disempitkan dalam pengertian pengajaran adalah suatu usaha yang bersifat sadar,tujuan yang sistematik terarah pada perubahan tingkah laku menuju kedewasan anak didik.perubahan yang di maksud itu menunjuk pada suatu proses akan dilakukan.Tanpa proses itu, tujuan tidak dapat dicapai dan proses yang dimaksudkan disini adalah proses pendidikan atau proses 
edukatif.

Selaku kepala sekolah dengan melihat proses belajar mengajar pelajaran $\mathrm{PKN}$ di kelas ternyata kemampuan siswa dalam memyelesaikan soal-soal atau tugas yang diberikan guru, baik berupa soal latihan, soal tugas pekerjaan rumah ataupun soal ulangan harian, sebagian besar belum dapat diselesaikan dengan baik, hal ini dapat terlihat pada waktu kegiatan pembelajaran di dalam kelas, masih banyak siswa yang tidak aktif menyelesaikan ataumengerjakan soal-soal atau tugas yang di berikan oleh guru, namun menunggu di papan tulis ada penyelesaian barulah aktif menulis.

Disamping itu, hal-hal yang menganggu dalam menyajikan materi di depan kelas, adalah banyak siswa yang lambat dalam menerima materi, tapi ada beberapa siswa yang agak cepat menerima materi yang di berikan sehingga membuat materi dijelaskan berulang-ulang. Namun demikian pada saat siswa mengerjakan soal-soal atupun tugas masih banyak pula yang belum dapat diselesaikan dengan baik.

Berdasarkan uraian di atas, maka kami sebagai kepala sekolah tertarik untuk mengadakan penelitian tentang penggunaan metode kelompok dengan bantuan tutor sebaya dalam menyelesaikan soal-soal atau tugas dalam proses belajar mengajar dengan harapan siswa yang memiliki kemampuan kurang dalam belajar baik berupa pengetahuan, sikap dan tinkah laku dapat termotivasi untuk memperoleh kemampuan yang lebih baik.

Berdasarkan permasalahan di atas, penulis tertarik untuk melaksanakan penelitian tentang: Penerapan Pembelajaran Metode Kerja Kelompok Untuk Meningkatkan Hasil Belajar Pkn Siswa Kelas V Semester Ganjil SDN 2 Ngali Tahun Pelajaran 2016/2017

\section{METODE PENELITIAN}

\section{Jenis Penelitian}

Penelitian ini adalah Penelitian Tindakan Kelas (PTK). Penelitian tindakan kelas (PTK) harus tertuju atau mengenai halhal yang terjadi didalam kelas (Aqib, 2007), yaitu: perencanaan, tindakan, observasi, refleksi

\section{Waktu dan Tempat Penelitian}

Penelitian ini dilaksanakan di SDN 2 Ngali, pada Semester I Tahun Pelajaran 2016/2017.

\section{Subyek Penelitian}

Subyek dalam penelitian ini adalah siswa Kelas V SDN 2 Ngali, Jumlah siswa 27 orang, Tahun Pelajaran 2016/2017.

\section{Prosedur Penelitian}

Adapun perencanaan dalam penelitian ini dirancang dalam dua siklus kegiatan yaitu $\therefore$

1. siklus pertama dirancang dilakukan selama tiga kali pertemuan.

2. siklus kedua dirancang dilakukan selama tiga kali pertemuan.

\section{Siklus I}

Siklus pertama berlangsung selama 3 kali pertemuan atau 6 x 4 menit. Standar kompetensi / kompetensi dasar pada siklus i sebagai berikut:

\section{Tahap Perencanaan.}

a. Menelaah kurikulum berbasis kompetensi (KBK) kelas V Semester ganjil mata pelajaran PKn

b. Membuat rencana pelaksanaan pembelajaran.

c. Membuat pedoman observasi untuk merekam kegiatan siswa dalam proses pembelajaran diskusi kelas.

d. Membuat alat evaluasi untuk melihat kemampuan siswa dalam menyelesaikan soal-soal.

2. Tahap Pelaksanaan Tindakan.

a) membagi siswa ke dalam beberapa kelompok, yang terdiri dan 4-6 orang siswa termasuk yang ditunjuk sebagai tutor sebaya untuk membantu temantemannya.

b) Guru memberikan motivasi kepada siswa, dan memberikan informasi tentang kompetensi dasar.

c) Guru bersama siswa membahas materi dan memberi contoh secara klasikal.

d) Guru memberi kesempatan kepada siswa untuk bertanya, apa bila masih ada yang kurang jelas.

e) Siswa bergabung pada kelompok 
untuk mengerjakan soal latihan atau soal yang diberikan guru.

f) Guru membimbing sambil mengamati siswa dalam kelompoknya.

g) Guru memberikan respon terhadap perilaku siswa dalam mengikuti kegiatan pembelajaran baik dalam menerima materi maupun dalam kelompok: misalnya memberikan teguran untuk memperhatikan teguran untuk memperhatikan, maupun dalam bekerja sama dengan temantemannya.

h) Guru menunjuk beberapa siswa untuk mengerjakan soal.

\section{Tahap Observasi dan Evaluasi.}

a. Mengamati kegiatan siswa melalui lembar obervasi.

b. Mencatatat beberapa kegiatan yang dianggap penting.

c. Pada akhir siklus pertama diberikan tes untuk melihat kemampuan siswa dalam menyelesaikan soal-soal.

d. Melaksanakan Evaluasi terhadap data yang telah diperoleh.

\section{Tahap Refleksi}

Dari hasil yang diperoleh dari tahap observasi dan evaluasi, guru akan dapat merefleksi diri, apakah kegiatan yang dilaksanakan telah dapat meningkatkan kemampuan siswa dalam menyelesaikan soalsoal. Hasil analisis data yang diselesaikan pada tahap ini akan digunakan sebagai acuan untuk melaksanakan tindakan pada siklus berikutnya.

\section{Siklus II}

Siklus kedua berlangsung selama 3 kali pertemuan atau $6 \times 45$ menit. Langkahlangkah kegiatan yang dilakukan pada siklus kedua pada umumnya merupakan pengulangan kegiatan yang dilakukan pada siklus pertama. namun diadakan beberapa perubahan antara lain:
a. Merumuskan tindakan selanjutnya berdasarkan hasil refleksi pada siklus I
b. Melaksanakan tindakan siklus II untuk melihat kemampuan siswa dalam menyelesaikan soal-soal.
c. Pada akhir siklus kedua diberikan tes
d. Menganalisis hasil tes dan hasil pengamatan pada siklus ii.

e. Setelah diadakan siklus kedua diharapkan hasilnyalebih baik.

\section{HASIL DAN PEMBAHASAN \\ A. Hasil Penelitian \\ Siklus I}

Analisis statistik deskripsi terhadap nilai tes Siklus I setelah pemberian tindakan melalui metode kerja kelompok dengan bantuan tutor sebaya menunjukan bahwa nilai rata-rata hasil belajar PKn siswa setelah pelaksanaan tindakan siklus I melalui metode kerja kelompok dengan bantuan tutor sebaya adalah 70,325, dan nilai tertinggi 95 sedangkan nilai terendah adalah 55 dengan standar deviasi adalah 9,679.

Jika nilai hasil belajar PKn siswa setelah melaksanakan tindakan Siklus I melalui metode kerja kelompok dengan bantuan tutor sebaya dikelompokkan kedalam lima kategori, seperti yang telah dijelaskan pada BAB III bagian tehnik analisis data. Dengan memodifikasi pengkategorian tersebut maka diperoleh distribusi frekuensi dan persentase, terdapat $0 \%$ siswa atau $0.00 \%$ yang memiliki hasil belajar PKn setelah pelaksanaan tindakan siklus I melalui metode kerja kelompok dengan bantuan tutor sebaya berada pada kategori sangat rendah maupun rendah, 27,50\% berada pada kategori sedang, $62,50 \%$ berada pada kategori tinggi dan $10,00 \%$ berada pada kategori tinggi. Jika nilai rata-rata hasil belajar PKn siswa setelah pelaksanaan tindakan Siklus I melalui metode kerja kelompok dengan bantuan tutor sebaya yakni 70,325yang dihubungkan dalam tabel kategori di atas, maka nilai rata-rata hasil belajar PKn siswa berada dalam kategori tinggi.

\section{Siklus II}

Dari analisis statistik deskripsi terhadap nilai tes Siklus II setelah pemberian tindakan melalui metode kerja kelompok dengan bantuan tutor sebaya bahwa nilai ratarata hasil belajar PKn siswa setelah pelaksanaan tindakan siklus II melalui metode kerja kelompok dengan bantuan tutor sebaya adalah 75,925, dan nilai tertinggi 98 sedangkan nilai terendah adalah 62 dengan standar deviasi adalah 9,395. Jika nilai hasil 
belajar PKn siswa setelah melaksanakan tindakan Siklus II melalui metode kerja kelompok dengan bantuan tutor sebaya dikelompokkan kedalam lima kategori, seperti yang telah dijelaskan pada BAB III bagian tehnik analisis data. Dengan memodifikasi pengkategorian tersebut maka diperoleh distribusi frekuensi dan persentase, terdapat $0 \%$ siswa atau $0.00 \%$ yang memiliki hasil belajar PKn setelah pelaksanaan tindakan siklus II melalui metode kerja kelompok dengan bantuan tutor sebaya berada pada kategori sangat rendah maupun rendah, 2,50\% berada pada kategori sedang, 77,50\% berada pada kategori tinggi dan $10,00 \%$ berada pada kategori tinggi, dan $20 \%$ berada pada kategori sangat tinggi.

Jika nilai rata-rata hasil belajar PKn siswa setelah pelaksanaan tindakan Siklus II melalui metode kerja kelompok dengan bantuan tutor sebaya yakni 75,925 yang dihubungkan dalam tabel kategori di atas, maka nilai rata-rata hasil belajar PKn siswa berada dalam kategori tinggi.

Untuk melihat peningkatan hasil belajar PKn siswa melalui metode kerja kelompok dengan tutor sebaya berdasarkan hasil tes sebelum pelaksanaa tindakan dan setelah pelaksanaan tindakan pada Siklus I dan Siklus II dapat dilihat bahwa rata-rata hasil belajar PKn siswa sebelum pelaksanaan tindakan melalui metode kerja kelompok dengan tutor sebaya adalah 61,400, rata-rata Siklus I adalah 70,325 dan rata-rata Siklus II adalah 75,925. Dari hasil ini menunjukkan adanya peningkatan rata-rata hasil belajar melalui metode kerja kelompok dengan bantuan tutor sebaya siswa kelas V SDN 2 Ngali.

Dari hasil di atas menunjukan pula bahwa adanya peningkatan ketuntasan hasil belajar yakni sebelum pelaksanaan tindakan tes awal 30,00\% yang tuntas, setelah pelaksanaan tindakan Siklus I, 72,50\% yang tuntas, dan Siklus II 97,50\% yang tuntas. Dari hasil ini diperoleh keterangan bahwa Siklus II ini telah mencapai ketuntasan belajar secara klasikal sebagaimana yang telah ditetapkan oleh Depdiknas bahwa tuntas belajar secara klasikal jika telah mencapai $85 \%$ dan jumlah siswa yang telah memperoleh skor minimal $65 \%$ dan skor ideal

\section{HASIL DAN PEMBAHASAN Siklus I}

Dari awal penelitian berlangsung hingga berakhirnya siklus I tercetat beberapa perubahan yang terjadi pada siswa seperti:

1. Perhatian siswa terhadap proses belajar mengajar sudah terlihat meningkat meskipun belum maksimal. Kemauan dan keseriusan nampak sekali terlihat pada tutor masing-masing kelompokuntuk senantiasa mengetahui materi yang diajarkan dengan mengajukan pertanyaan tentang materi yang belumdimengerti.namun pada pertemuan ketiga sampai selesai, siswa terlihat aktif dibanding dengan pertemuan pertama dan kedua. Siswa sudah ada dan anggota masing-masing kelompok yang sering mengajukan pertanyaan pada setiap pertemuan.

2. Keberanian siswa bertanya dan menjawab soal yang diberikan juga meningkat. Hal ini terlihat dengan adanya beberapa siswa yang ingin mengerjakan soal-soal yang diberikan oleh guru.

3. Jumlah siswa yang mengerjakan soal-soal yang diberikan masih kurang atau sekitar rata-rata 7 orang setiap pertemuan.

4. Kerjasama pada setiap kelompok masih kurangsehingga perlu bimbingan oleh tutor sebaya atau guru.

\section{Siklus II}

Pada saat berlangsungnya siklus II beberapa perubahan yang terjadi pada diri siswa antara lain:

1. Perhatian siswa terhadap proses belajar mengajar semakin meningkat . hal ini dapat dilihat dari kelompok sangat aktif dalam mengikuti proses-proses dari setiappengembangan konsep dan kehadiran siswa pada siklus ini $100 \%$ dari empat kali pertemuan.

2. Kemauan siswa dalam menjawab soal yang diberikan juga meningkat. Hal ini terlihat banyak siswa yang mampu mengerjakan soal-soal latihan dengan benar pada setiap pertemuan.

3. Semangat siswa untuk mengerjakan soal yang diberikan juga meningkat. Hal ini terlihat pada pemberian soal latihan siswa pada setiap kelompok tidak ragu-ragu lagi 
mengerjakan soal yang diberikan oleh guru.

4. Kerjasama pada setiap kelompok masih kurangsehingga perlu bimbingan oleh tutor sebaya atau guru.

5. Kerja sama dari masing-masing anggota kelompok sangat aktif dan banyaknya pertanyaan yang diajukan siswa baik kepada tutornya maupun kepada penelitiberkisar antara 10-15 orang.pada tiap pertemuan pada siklus ini. Hal ini juga terlihat tidak ada siswa yang meninggalkan kelas atau bermain saat pembelajaran berlangsung.

Pada pekan awal pelaksanaansiklusI, semangat dan keaktifan siswa dalam mengikuti proses belajar mengajar masih kurang. hal ini mungkin disebankan karena pada siklus I, kelompok belajar dalam kelas dibagi menjadi 4 kelompok dengan masingmasing 6 sampai 7 orang. pembagian kelompok dengan jumlah anggota yang banyak terlihat terlihat tidak efektif sebab tutor tidak mampu mengatasi kesulitan yang dialami anggota kelompoknya mengenai materi yang telah diajarkan sehingga semangat belajar hanya terlihat pada siswa yang memang sudah mempunyai semangat belajar sebelum penelitian ini dilaksanakan.

Semangat dan perhatian siswa untuk mengikuti proses pembelajaran pada Siklus I masih rendah, hal ini terlihat bahwa masih banyaknya siswa yang tidak memperhatikan pembahasan materi pembelajaran. Dan siswa yang dapat menjawab pertanyaan yang diajukan peneliti pada saat pengembangan pemahaman konsep masih kurang atau hanya berkisar antara 3 dan 4 orang setiap pertemuan dan banyaknya siswa yang mampu menjawab soal dengan benar pada penerapan konsep serta siswa yang menyelesaikan soal-soal pada papan tulis hanya berkisar 3 sampai 6 orang pada tiap pertemuan.

Dari beberapa hal di atas dapat dikatakan bahwa interaksi belajar mengajar kurang nampak. Siswa yang aktif memberikan memberikan respon pertanyaan, komentar, dan tanggapan hanya siswa yang tergolong pintar atau siswa yang memperoleh nilai baik pada ulangan harian atau semester sebelum penelitian ini dilaksanakan.
Berdasarkan hasil refleksi pada Siklus I, pada Siklus II ini kelompok belajar dibagi menjadi 5 kelompok dengan anggota masingmasing 5 orang dengan pembagian kelompok tersebut semangat siswa dalam mengikuti proses belajar mengajar sudah mulai meningkat. Hal ini dapat dilihat tutor pada tiap kelompok sudah mampu mengakomodasi kesulitan yang alami oleh anggotanya, dalam hal ini, dalam hal ini materi pelajaran yang telah diajarkan.

Dengan diubahnya kelompok belajar dengan memperkecil jumlah anggotanya siswa lebih bersemangat dalam belajar. Hal ini disebabkan karena anggota-anggota kelompok sudah merasa senang dan lebih akrab.

Semangat siswa untuk mengikuti proses belajar mengajar padasiklus ini sudah meningkat. Hal ini dapat dilihat bahwa siswa yang memperhatikan pembahasan materi pelajaransekitar $100 \%$ dan siswa yang dapat menjawab pertanyaan yang diajukan peniliti pada saat pengembangan konsep berkisar antara 8 sampai 14 orang tiap pertemuan. Dan banyak siswa yang mampu menjawab soalsoal dengan benar pada penerapan konsep, serta siswa yang mau menyelesaikan soal-soal pada papan tulis berkisar antara10 sampai 20 orang setiap pertemuan.

Dari beberapa hal di atas dapat dikatakan bahwa interaksi belajar mengajar pada siklus II ini sangat meningkat, sebab siswa yang aktif memberi respon. Pertanyaan dan anggapan bukan hanya siswa yang tergolong pintar atau yang mempunyai nilai baik pada ulangan sebelumnya.

\section{KESIMPULAN}

Berdasarkan hasil pembahasan diatas dapat disimpulkan bahwa:

1. Rata-rata hasil belajar PKn siswa sebelum penelitian tindakan kelas adalah 16,244 dan skor ideal yang mingkin dicapai yaitu 25 , sedangkan rata-rata hasil belajar PKn siswa setelah diadakan tindakan kelas melalui metode kerja kelompok dengan bantuan tutor sebaya dan dua siklus yaitu Siklus I adalah 27,089 dan siklus II adalah 30,60 , dan skor ideal yang dicapai yaitu 40. Dari hasil tersebut diperoleh 
keterangan bahwa hasil belajar PKn dalam hal ini kemampuan menyelesaikan soalsoal siswa kelas V SDN 2 Ngali mengalami peningkatan.

2. Adanya peningkatan ketuntasan hasil belajar yakni sebelum diadakan tindakan tes awal 35,56\%) yang tuntas, setelah diadakan tindakan siklus I $72,50 \%$ yang tuntas, dan Siklus II 97,50\% yang tuntas. DARI Hasil ini diperoleh keterangan bahwa siklus II ini telah mencapai ketuntasan belajar secara klasikal sebagaimana yang telah ditetapkan oleh Depdiknas bahwa tuntas belajar secara klasikal jika telah mencapai $85 \%$ dari jumlah siswa yang telah memperoleh skor minimal $65 \%$ dan skor ideal.

\section{DAFTAR PUSTAKA}

Ajoku, L. I. (2013). Professional development Depdikbud. 1993. Kurikulum Sekolah Lanjutan Tingkat Pertama(SLTP) Petunjuk Proses Belajar Mengajar. Jakarta. Depdikbud

Depdikbud. 1994. Petunjuk Proses Belajar Mengajar. Jakarta. Balai Pustaka

Djamarah, dkk 1996. Stategi Belajar Mengajar. Jakarta:Renika Cipta.

Hasibuan. JJ JJ dan Moedjion0, 1995. Proses Belajar Mengajar. Bandung: Reharja Rosdarja

Heinnz Kock, 1995. Saya Guru Yang Baik. Yogyakarta : Kanisius

Muhammad Jasri Djangi, 1994. Jurnal Ilmiah Pendidikan MIPA Vol. I Nomor I. Ujung Pandang. FMIPA IKIP Ujung Pandang

Nasution S. 1986. Didaktik asas-asas Mengajar. Bandung. Jemmars

Nasution S. 1995. Didaktik asas-asas Mengajar. Jakarta. Bumi Aksara

Poerwandarminto W.J.S. 1984. Kamus Besar Bahasa Indonesia. Jakarta. Balai Pustaka

Roestiyah NK. 1989. Masalah-masalah Ilmu Keguruan. Jakarata: Bumi Aksara

Syaiful Bakri. 1994. Prestasi Belajar dan Kompetensi Guru. Surabaya: Usaha Nasional

Team Dikdaktik Metodik. 1993. Pengantar Dikdaktik metode kurikulum proses belajar mengajar. Jakarta: Raja Grasindo Persada

Winarto Surakhman. 1994. Pengantar Interaksi Mengajar Belajar. Bandung: Tarsito. 